\title{
Cultural Aspect Management Model for Organization Development of Naval Education Department of the Royal Thai Navy
}

\author{
Arkom Suktragool $^{1}$, Kla Somtrakool $^{1} \&$ Pairat Thidpad $^{1}$ \\ ${ }^{1}$ The Faculty of Cultural Science, Mahasarakham University, Khamriang Sub-District, Kantarawichai District, \\ Maha Sarakham Province, Thailand \\ Correspondence: Arkom Suktragool, The Faculty of Cultural Science, Mahasarakham University, Khamriang \\ Sub-District, Kantarawichai District, Maha Sarakham Province 44150, Thailand. E-mail: \\ asuktragool150@gmail.com
}

Received: May 9, 2014 Accepted: June 6, 2014 Online Published: June 12, 2014

doi:10.5539/ach.v6n2p163

URL: http://dx.doi.org/10.5539/ach.v6n2p163

\begin{abstract}
This is a qualitative investigation aimed at analyzing the organizational culture of the Naval Education Department of the Royal Thai Navy and determining a cultural aspect management model to decrease the culture gap and promote unity in diversity. Research was conducted over a ten month period from November 2012 to August 2013. The study area was purposively selected and was composed of naval departments in three provinces: Bangkok, Nakhon Pathom and Chonburi. Data was collected by document study and field research. The tools used for data collection in the field were basic survey, participant and non-participant observation, structure and non-structured interview and focus group discussion. There are three major responsibilities of the Naval Education Department (NED). They are: 1) Education and Training; 2) Research; and 3) History. There are six categories of problems with the NED culture: structure, administration policy, leadership, manpower utilization, shared value and morals. The Cultural Aspect Management Model for Organization Development of Naval Education Department of The Royal Thai Navy is the 'LISIS' model, which is composed of leadership, inspiration, strategy, identity and shared values.
\end{abstract}

Keywords: Royal Thai Navy, education, culture, organization, development, management

\section{Introduction}

Government organizations and the private sector need to develop and compete continuously in order to perfect their services and meet the needs of their customers (Denison, 1990). Organizations need to maximize their use of resources to achieve management success (Hofstede, 1997; Schein, 1992). At present, manpower is the most important resource and asset of most organizations but manpower must be linked to corporate values to instill commitment in the workforce (Peters \& Waterman, 1982). Workers must represent the organizational or corporate culture, which includes beliefs, values and shared behavior in the form of words, concepts, learning and actions (Patterson, 1988; Robbins \& De Cenzo, 2004; Saffold, 1988). The success or failure of this will lead to the achievement or bankruptcy of the organization (Chantachon, 2010). Nowadays, acculturation processes are used in organizations to increase the ability of competition and vitality (Boonkhwan, 2006). There are many different types of organizational culture but the management of corporate culture is the process to increase efficiency and effect actions through manpower and organization resource management (Maharatsakul, 2004; Robbins \& Coulter, 2002).

\subsection{Re-organization of Ministry, Bureau and Department Act, B.E. 2545}

This 2002 act led a huge reform of government organizations and preceded the reformation of the Ministry of Defense structure according to the Re-organization of the Ministry of Defense Act, B.E .2551 (2008) and the royal decree organizing Royal Thai Navy, B.E. 2551 (2008). The Royal Thai Navy was divided into 36 divisions. The Naval Education Department (NED) and Institute of Advanced Naval Studies (IANS) were combined so there were many academic levels in the Naval Education Department (NED). There were nine divisions in the former Naval Education Department (NED), which provided education for the non-commissioned officers with low undergraduate degrees so that they may become the main component of Royal Thai Navy manpower. There were nine divisions in the former Institute of Advanced Naval Studies (IANS), which provided education for commissioned officers with post-graduate qualifications so that they may work in higher-level positions. The two 
organizations were combined with 16 divisions with different missions, set by the Naval Education Department (NED). Although they had similar missions, there were some problems with management, such as problems with the chain of command, cooperation, division of labor, work assignment and unity of command. These led to problems of work delays and duplications and there was a gap in culture because of different values, traditions and cultural aspects between the two organizations. Given these issues, the research team was interested in determining a cultural aspect management model to decrease the gap and promote unity in diversity.

\subsection{Unity in Diversity: Institute of Advanced Naval Studies (IANS) and Naval Education Department (NED)}

The Institute of Advanced Naval Studies (IANS) was a department controlled by the Royal Thai Navy and its structure was divided into nine divisions: headquarters, department of academic affairs, Naval Strategic Studies Center, Naval War College, Naval Command and Staff College, Senior Naval School, Line Officers School, Engineering Officers School and Supporting Division. IANS was reformed to be a division of NED and NED became an independent department in 1903. There were nine divisions in the former structure: headquarters, department of academic affair, Visual Aids Division, Chaplaincy Division, Royal Thai Naval Institute, Non-Commissioned Officers School and Recruit Training Center. NED (new) has been reformed and manage their manpower, which is controlled by the Royal Thai Navy according to the royal decree organizing the Royal Thai Navy in 2009. At present, the NED is divided into 16 divisions, as has been the case since $1^{\text {st }}$ April 2009: headquarters, department of academic affairs, Naval War College, Naval Command and Staff College, Line officers School, Non-Commissioned Officers School, Naval Rating School, Recruit Training Center, Language Center, Naval Strategic Studies Center, Educational Service Division, Library Division, Historical Division, Chaplaincy Division and Supporting Division. The NED had its $110^{\text {th }}$ anniversary on $3^{\text {rd }}$ May 2013.

\subsection{Naval Education Department (NED), Royal Thai Navy}

'The Iron in humans is more important than the iron in the ship.' This slogan is the dharma puzzle that the naval progenitors left behind to remind their descendants and is accepted by the worldwide navy. Its meaning is that the efficiency of manpower is the most important element in or on a warship. The progenitors established the Royal Thai Navy to protect the long straight line of the Thai coast rather than attack any party. Therefore, The Royal Thai Navy has trained manpower to be efficient in different fields to build up naval efficiency even though the country is at peace. This is to utilize the manpower and to empower the organization in order to achieve the settled objective of protecting the country. The Royal Thai Navy realizes the importance of human resource development. Therefore, the Naval Education Department (NED), the principal organization in the Royal Thai Navy that is responsible for providing education to all levels of Royal Thai Navy officers was assigned to provide education to all staff in order to build up strength, both physically and mentally. Additional aims were to promote capable officers with morals, integrity and unity to be ready to support the country whenever global changes occurred. The officers were to be able to cope with different kinds of threats and dangers. The Naval Education Department (NED) is a quality and efficient organization to produce and develop manpower with knowledge, capabilities and qualifications befitting the navy, as well as morals and ethics according to the aims of the Royal Thai Navy. The NED's duties are: superintendence, liaison, advisory, regulation and administration on training and textbooks, chaplaincy, history and soldier's museum, education management, analysis and evaluation of the strategies and military doctrine assignments, including training on naval academic programs, which involve the direct control of the academy and the director of the Naval Education Department.

\subsection{NED Policy According to the Annual Budget of 2013}

\subsubsection{The General Policy}

- $\quad$ To produce, develop and adjust the standards and transparency of major and minor missions by supporting manpower participation and teamwork.

- High efficiency management in human resources, material resources, budget and information technology through the resource restriction.

\subsubsection{The Education Policy}

- To manage an active learning education, support assertiveness, participate in education and creative activities.

- To educate and encourage basic experience for naval operation in both naval command and supporting division.

- Use all kinds of information technology to support administration, education and training. 
- To improve the location and provide good education materials which are sufficient for education and research management.

\subsubsection{The Manpower Policy}

- To train, build an amor patriae conscience towards Thailand, religion and the King, including the morals, ethics, unity and harmony.

- To support and encourage manpower with knowledge, talent and sacrifice for advancement in government service.

- To be accurate in consideration and shift positions by focusing knowledge and capacity.

\subsubsection{The Fringe Benefits Policy}

- To improve the infrastructure and facilities, provide and build public utilities, including improvements to the external and internal landscape for work and habitat.

- To manage the high quality of NED's fringe benefits for manpower, their families and a proper social environment.

- To educate the manpower and their families in order to live according to the sufficiency economy and stay free from narcotics, keep good health and good morale.

\section{Methodology}

This is a qualitative investigation aimed at analyzing the organizational culture of the Naval Education Department of the Royal Thai Navy and determining a cultural aspect management model to decrease the culture gap and promote unity in diversity. Research was conducted over a ten month period from November 2012 to August 2013. The study area was purposively selected and was composed of naval departments in three provinces: Bangkok, Nakhon Pathom and Chonburi. Forty-five individuals were purposively selected to form the sample population and were divided into three groups: key informants $(n=10)$, casual informants $(n=30)$ and general informants $(\mathrm{n}=5)$.

Data was collected by document study and field research. The tools used for data collection in the field were basic survey, participant and non-participant observation, structure and non-structured interview and focus group discussion. All gathered data was validated using a triangulation method and analyzed in categories according to the aims of the research by analytic induction and typological analysis. The results are here presented as a descriptive analysis.

\section{Results}

\subsection{Current Situation and Identity of the Naval Education Development (NED)}

According to the organizational culture of the Naval Education Development, which is the backbone of manpower production, work on manpower development and NED is also the think tank of the Royal Thai Navy. There are three major responsibilities of the NED. They are: 1) Education and Training; 2) Research; and 3) History. The special educational characteristics are as follows.

The Naval Education Department designed the curriculum in an active learning way, starting from executive rank and commodore to navy officer. The curriculum emphasizes critical thinking, problem solving and learning by using the work plan as a basic strategy. There are six educational institutions under the NED's supervision.

The Recruit Training Center is responsible for training Thai men who are recruited to work as navy officers. There are over 4,000 men recruited as seamanship mariners each year. These men will be on discipline training; they should know about the navy traditions in order to be a naval representative and a gentleman

The Naval Rating School is responsible for civilian recruitment of officer cadets and provides specific training for them. Once these students graduate, they are professional navy officers and able to work efficiently as a part of the warship navy and work in other organizations under the Royal Thai Navy's supervision.

The Non-Commissioned Officer School is responsible for providing knowledge and training to the non-commissioned officer students.

The Line Officers School is the organization that provides knowledge to the commissioned officers who attend Marine Curriculum, Naval Architecture Curriculum, General Curriculum and Additional Curriculum in order to teach about primary knowledge for a Chief of Staff in the Royal Thai Navy, knowledge of primary administration and management and ability to perform naval tasks at a strategic level, with the ability to work as a young executive. 
The Naval Command and Staff College is responsible for providing knowledge to commissioned officers after they have been working as supervisors for a while. There are two curriculums: 1) Naval Staff Curriculum Program - the purpose is to train the student to work as a naval officer so that they are able to work in the administration department, able to administer tasks at squadron level and able to lead a strategic warship unit; 2) The Curriculum for the Senior Navy - this curriculum is provided for the senior navy who would like to work at a middle executive level.

The Naval War College is the school that provides the highest curriculum of the Royal Thai Navy. This school provides training for students to be able to work as navy leaders at the strategic level, who are able to command warships at the navy corps level. They should be able to work with international navies, able to determine policy, prepare strategic plans for their own unit and also with other military groups or other organizations involved with maritime activities.

The NED was assigned by the Royal Thai Navy to perform research about strategic and maritime stability. For example, research regarding battleships, maritime operation in different fields, military doctrine, military operation, related law, rules of engagement, technology, principals and theories of organization administration, governmental administration, military administration, leadership, hierarchy, roles and responsibility of the administration department, roles and responsibility of chief of staff and specific research assigned by the Royal Thai Navy.

There are two major responsibilities concerning history, which are: 1) consolidating historical evidence and lessons learned from history. The NED collects evidence of past and present operations for study and analysis in terms of strategy and policy; 2) study of the relationship among politics, the military, people and wrong operations that occurred in the Royal Thai Navy in the past. These items are filed as lessons learned and passed to naval students in different curriculums.

\subsection{Problems with the NED Culture}

The current problems of the NED culture can be categorized into six items:

\subsubsection{Structure}

Integration of educational units containing different characters in terms of manpower production and knowledge development weaken the culture. When many units are combined without task analysis that considers work as a priority, it results in self-benefit taking. Unclear structure causes unclear implementation which has been the root of this problem since the beginning. Organizing a big educational structure that consists of 16 units is not an obvious centralization, especially the organizations that are handled by one supervisor. It does not cover a span of control. In addition, NED has many branches in other provinces. Therefore, the NED's academic structure is loose.

\subsubsection{Administration Policy}

The guidelines are wide in order to achieve the vision. That is why the turnover rate of unit leaders is very high and this results in inconsistent policy, interruptions and physical disconnection from the work process. The operations in the past maintained policy level only and there were no job descriptions until now. The administration policy does not pay attention to the value of historical data that the navy has been trying to maintain.

\subsubsection{Leadership}

The unit leaders should have a focused vision and they have to be good models, having prompt behavior, good practice and morals that enable them to overcome differences in the department in order to build up unity and bonding. The unit leaders should have perception of the basic education system, especially higher education because the leaders have to dedicate themselves to train people to be strong in both discipline and naval knowledge with creativity and continuous ideas. The leaders should deploy a meritocracy and not think of their own benefits.

\subsubsection{Manpower Utilization}

The manpower is not sufficient for the working structure. Therefore, the relationship is not harmonized; each person does their own job. The academic section is not allocated a sufficient number of instructors suitable for the number of students in each semester. The Naval Education Center is considered as the think tank of the Royal Thai Navy that analyzes the strategy but cannot respond to the Royal Thai Navy efficiently. There is a lack of rotation within the organization in order to create knowledge exchange and learning between commissioned and non-commissioned officers. For the supporting units, they are responsible for an area of 252 rai, which is a 
huge area and makes performance inefficient.

\subsubsection{Shared Value}

The NED was established from the basic values of people who believed that their selected culture was formed from basic education and applied for people used to working at a high level. They believed that their culture is based on high education and, when these units are combined, the officers usually behave appropriately. Sometimes, people are divided into different groups; each group consists of people who believe in the same thing. There is no harmonization between groups. This matter can be compared with a canal that is located between two buildings. If we would like to change shared values we need to change behavior not the objective.

\subsubsection{Morals}

Since the NED was combined into one academic institution that consists of 1,720 navies, it is a big organization. Currently most of the officers lack morals regarding their career growth in education. Lots of officers are stuck at lieutenant commander and navy-commander level and cannot be promoted to a higher level because there is no position to support the promotion. In addition, there is a non-meritocratic system of informal relationships. As a result, injustice occurs and people are divided into groups. This matter discourages the officers who intend to work but see no career growth.

\section{Discussion}

\subsection{Guidelines for Culture Development of the Naval Education Department (NED)}

The guidelines for culture development can be divided into 4 strategies as follows:

\subsubsection{Strategy 1}

The NED structure improvement consists of different measures. Firstly, a committee and working team should be set up to work on NED structure improvement and to determine the framework of NED educational structure to be more compact, more appropriate and able to balance the workload and reduce duplication among sections. The working group could be divided into school, academic, service, support and administration leading to the purpose that NED would approach tasks with the utmost efficiency and efficacy of educational implementation. Secondly, the NED task force must be improved. Regarding positions and ranking of NED structure and mission, the task force should be determined appropriately and outsource recruits in order to train people as qualified naval officers by providing basic education and work on manpower development that requires higher education. Therefore, qualified personnel are required as naval specialist trainers in specific fields. Thirdly, a document should be created to specify the scope and responsibility of specific positions with a description of work in order to provide clear instructions of work operation. Currently, there is no job description available for each position at NED but it is recommended.

\subsubsection{Strategy 2}

Strategy 2 is aimed at building up vision and leadership. There must be a good perception of the educational system. To support the achievement of the organization's vision, a leader should be appointed with a love of education and an understanding of the basic educational system. It is recommended to train the navy with discipline, a basic naval education and higher education system that require further training in accordance with government guidelines. Morals and ethics are at the heart of the work. The leader should be trusted and able to build up credit to show their supervision in the organization because the leader should be a good model, who is honest and considers public benefit rather than self-benefit. Students may then follow this role model to become a good government officer. There must be a meritocratic system. The leader should build up justice in order to create morals in the organization, promote qualified personnel, people who work hard and show loyalty to career progression. As a result, the government officers will focus on success and achievement rather than informal relationships. A meritocratic system is appropriate for organizations that provide education and training to people in order to build conscious staff. These staff members will be able to apply the knowledge obtained to develop their organizations in the future.

\subsubsection{Strategy 3}

The manpower administration system must be built up by rotating the commissioned officer positions between those officers working in a high level education unit and those officers working in a basic level education unit. Rotation will enable the officers to exchange their knowledge and work experience; it is a way to reduce the gap that occurs in the culture that usually separates people into different groups. This system will gather people in one group, encouraging them to help each other in the future. Despite the need for rotation, there must be proper criteria in place to rotate the non-commissioned officers. There should be determination to move warrant officers 
who have completed their term every two years and sergeants every three years because both positions are in the same career group and workers are able to replace one another position. This method will help the department to create and develop their work and does not cause boredom for officers doing a routine job.

\subsubsection{Strategy 4}

The shared value of the organization must be adjusted by building up participation to open opportunities for everyone to share their ideas in a creative way, to listen to comments and recommendations that would help to reduce contrast and misunderstanding. Clear and good communication channels would create understanding in the same way, reducing the gap between supervisor policy and operation officers and encouraging close relationships. Seminars should be organized regularly in order to support knowledge exchange and learning, both inside and outside. This would create a good learning atmosphere and strengthen working relationships in the office. It would constructive to invite retired honored officers to share their direct experience to active officers in order to make good connections between two different cultures. In addition, it would build up good attitudes and work inspiration among the officers to focus on public benefits. Communal recreation activities should be organized. Routine work is boring for officers and it is recommended that relaxed activities reinforcing work atmosphere are arranged to make people feel happy at work. People would feel greatly empowered at work because it would increase the value of their work. For example, a navy sports day can be organized. This is a navy tradition but is not frequently organized. This kind of activity could help to for , stronger bonds among naval personnel.

\subsubsection{Strategy 5}

The administrative policy must be clear and continuous. The administration policy has to be available in writing. The supervisor or head of the academic unit should determine the policy in writing, especially for large tasks with broad structures, in order to make it clear and easy in practice. There must be understanding about the administration policy guidelines and policy adjustment with clear practical guidelines and concrete indicators. The administration policy needs to be continuous. Most supervisors in the academic unit are usually rotated during the annual rotation. This results in discontinued policy; sometimes the policy is deployed according to informal relationships. To build up education connections, the policy needs to be continued and the administration policy need to be determined in order to cover the tasks of the unit that could be able to support whenever rotation has occurred or the policy could be adjusted upon changes of the circumstance.

\subsection{Cultural Aspect Management Model for Organization Development of the Naval Education Department of the Royal Thai Navy}

The analysis of current identity of culture and the problems of organization are: organizational structure, administration policy, leadership, manpower policy, shared value and morale. The conclusion of this investigation is a 'LISIS' model, as described below.

\subsubsection{Leadership}

The most important aspect of organization development is the leaders. They should have knowledge and capacity to build enthusiasm for credible teamwork. NED's leaders should understand the fundamentals of change in the combination of two organizations. They should lead big changes by understanding the same shared values and devotion to work according to policies of empirical work. They need to study new techniques from good prototypes. NED's leaders need to adhere to morals in administrative rotation by determining decisions from knowledge and capacity with justice, equality and morality. They should act with consistent standards. NED's leaders are the prototypes of honesty and act with the best practices and honest intentions. They command and act without bias and favoritism. They foster and create a conscience of honesty and look down upon dishonesty.

\subsubsection{Inspiration}

Power is obtained from the spirit, which is the essence in people's minds or consciences that determines their actions. People derive inspiration from their heroes. The heroes of NED officers are King Bhumibol Adulyadej, supreme commander and Admiral Prince Abhakara Kiartiwongse, the father of the Royal Thai Navy.

\subsubsection{Strategy}

The NED has a large-scale structure which contains all academic work so there should be strategies to manage culture for development. To reform the NED's structure a committee and working group should be set up in order to consider manpower, mission, administration, research, history and supporting divisions. Manpower must be appointed at its full quota in order to complete schooling and the curriculum, including concrete standards of manpower rotation in order to encourage academic officers and provide opportunity for advancement in military 
service. Curriculum management should be adjusted properly according to environmental change and contemporary situations. History is the root of the navy and should be contained in the curriculum for the benefit of future education analysis. Historical missions are very important in determining future Royal Thai Navy strategy. Public utility suitably must be assessed, such as workplace, classroom, meeting room, canteen, day room and landscape architecture.

\subsubsection{Identity}

The NED has three identities, which are education, research and history. These relate to one another and build academic excellence and public acceptance. For education, there are academies in control, such as the Naval War College, Naval Command and Staff College, Lines officer School, Naval Rating School, Non Commission Officer School and Recruit Training Center. For research, the NED is committed by the Royal Thai Navy to research about the strategies and security concerning the sea. For history, the main missions are to gather historical evidence of the Royal Thai Navy and research lessons learned from history.

\subsubsection{Shared Value}

Shared values for good culture are to be encouraged by using 'SMART' principles:

S: Seamanship, which means solidarity, acceptance of others, responsibility, teamwork and adherence to naval traditions.

M: Mastery, which means enthusiasm for education, continuous search for knowledge by adhering to justice, support for work, updated information and mastery of work.

A: Ambition, which means harmonious aims, characteristics and educational achievement education. The graduates should have morals, ethics, discipline and skill in the navy profession.

$\mathrm{R}$ : Reliability, which means confidence in the naval academy as a source of manpower generation to develop the capacity of efficient and effective naval officers.

T: Teamwork, which means everyone works with one another, compromising differences in people and work processes in order to reach divisional, departmental, ministerial and national strategies with trust and acceptance.

\section{Conclusion}

The Cultural Aspect Management Model for Organization Development of Naval Education Department of The Royal Thai Navy is the 'LISIS' model, which is composed of leadership, inspiration, strategy, identity and shared values. These will be integrated together. If the sea is the best trainer for seamanship, the officers of the NED are the best teachers for building the iron of the Royal Thai Navy manpower to achieve its vision.

\section{References}

Boonkhwan, T. (2006). Organizational culture and strategy [in Thai]. Bangkok: Chulalongkorn University Press.

Chantachon, S. (2010). Culture and social theory [in Thai]. Mahasarakam: The Research Institute of North-eastern Art and Culture.

Denison, D. R. (1990). Corporate culture and organizational effectiveness. New York: John Wiley and Sons.

Hofstede, G. H. (1997). Cultures and organization: Software of the mind. London: McGraw-Hill.

Maharatsakul, P. (2004). Culture organization: Hidden power for the success of work management and operation [in Thai]. Bangkok: Chulalongkorn University Press.

Patterson, K. J. (1988). School culture. San Francisco: Jersey Bass.

Peters, T. J., \& Waterman, R. H. (1982). In search of excellence: Lessons from America's best-run companies. New York, NY: Harper \& Row.

Robbins, S. P., \& Coulter, M. (2002). Management. New York, NY: Prentice Hall.

Robbins, S. P., \& De Cenzo, D. A. (2004). Fundamentals of management: Essential concepts and applications (4th ed.). Upper Saddle River, N.J: Pearson.

Saffold, G. S. III. (1988). Culture traits, strength and organizational performance: Moving beyond strong culture. Academy of Management Review, 13(4), 546-558.

Schein, E. H. (1992). Organizational culture and leadership (2nd ed.). San Francisco, CA: Jossey-Bass. 


\section{Copyrights}

Copyright for this article is retained by the author(s), with first publication rights granted to the journal.

This is an open-access article distributed under the terms and conditions of the Creative Commons Attribution license (http://creativecommons.org/licenses/by/3.0/). 